\title{
RENOVASI FISIK DAN PENANAMAN 3000 POHON MANGROVE OLEH CORPORATE SOCIAL RESPONSIBILITY (CSR) PT. PERTAMINA (PERSERO) MOR I - DUMAI DI DESA WISATA KAMPUNG NELAYAN KELURAHAN PANGKALAN SESAI KECAMATAN DUMAI BARAT KOTA MADYA DUMAI
}

\author{
Adek Cerah Kurnia Azis ${ }^{1 *}$, Mesra $^{1}$, Muslim ${ }^{1}$ \\ ${ }^{1}$ Jurusan Seni Rupa, Fakultas Bahasa dan Seni, Universitas Negeri Medan, Medan, Indonesia \\ *Penulis Korespondensi: adek_peros@yahoo.com
}

\begin{abstract}
Abstrak
Kegiatan yang dilakukan oleh Corporate Social Reponsibility (CSR) PT. Pertamina (Persero) MOR-1 Terminal Bahan Bakar Minyak (TBBM) Dumai yakninya renovasi fisik bangunan dan pelestarian hutan mangrove dengan melakukan penanaman 3000 pohon mangrove di Desa Desa Wisata Kampung Nelayan Kelurahan Pangkalan Sesai, Kecamatan Dumai Barat, Kota Madya Dumai. Hal ini bertujuan untuk perbaikan konstruksi bangunan yang rusak dan pembangunan kembali bangunan-bangunan yang tidak layak pakai, sehingga fasilitas bangunan yang ada di desa ini menjadi lebih baik. Berikutnya penanaman 3000 pohon mangrove dengan tujuan untuk melestarikan ekosistem mangrove, hewan laut, peminimalisiran abrasi, kembalinya burung-burung bersarang ke tepi pantai pesisir, pengantisipasian gelombang bencana tsunami menjadi lebih minimalist, dan menjadikan desa ekowisata mangrove yang asri. Metode pelaksanaan kegiatan ini yaitu dengan melakukan perbaikan, rehabilitasi, edukasi, sosialisasi, pelatihan, dan pengaplikasian, yaitu dengan capaian yang telah dihasilkan pada kegiatan ini. 1) renovasi fisik fasilitas umum di kawasan wisata desa kampung nelayan, dapat di kategorikan pada peningkatan membaik dengan persentase mencapai pada $75 \%$ dalam perubahan fisik bangunan yang ada di kawasan wisata desa kampung nelayan, selanjutnya untuk kegiatan penanaman 3000 pohon mangrove mengalami peningkatan jumlah pertumbuhan mangrove kepada kategori membaik, dengan capaian persentase $78 \%$. Kegitan ini tentunya memberikan kontribusi yang sangat berarti bagi perkembangan Desa Wisata Kampung Nelayan menjadi lebih baik lagi dengan kondisi fasilitas yang lebih baik dan pelestaraian hutan mangrove lebih berkontribusi terhadap lingkungan sekitarnya.
\end{abstract}

Kata Kunci: Renovsi Fisik, Penanaman 3000, Mangrove, Kampung Nelayan,CSR Pertamina, Dumai

\begin{abstract}
Activities carried out by Corporate Social Responsibility (CSR) PT. Pertamina (Persero) MOR-1 Dumai Fuel Oil Terminal (TBBM) believes that the physical renovation of the building and the preservation of mangrove forests is by planting 3000 mangroves in the Village of the Village of Fishermen's Village, Pangkalan Sesai Village, Dumai Barat District, City of Dumai. This aims to improve the construction of damaged buildings and rebuild buildings that are not suitable for use, so that the building facilities in this village are better. Next, planting 3,000 mangrove trees with the aim of preserving mangrove ecosystems, marine animals, minimizing abrasion, returning birds nesting to the coastline of the coast, anticipating the tsunami disaster to become more minimalist, and making the village a beautiful mangrove ecotourism. The method of implementing this activity is by making improvements, rehabilitation, education, socialization, training, and application, namely with the achievements that have been generated in this activity. 1) physical renovation of public facilities in the fishing village village tourism area, can be categorized as improving improvement with the percentage reaching $75 \%$ in the physical changes in the existing buildings in the fishing village villages, then for the planting of 3000 mangrove trees experienced an increase in mangrove growth to the improved category, with a percentage achievement of $78 \%$. This activity certainly contributes significantly to the development of the Fishermen Village Tourism Village to be even better with better facility conditions and the preservation of mangrove forests contributes more to the surrounding environment.
\end{abstract}

Keywords: Physical renovation, 3000 planting, mangrove, fisherman village, CSR Pertamina, Dumai 


\section{PENDAHULUAN}

Keberadaan ekosistem tumbuhan mangrove di Indonesia sekarang ini berada pada kedudukan yang sangat membahayakan, mengingat untuk memenuhi keragaman kebutuhan manusia yang jumlahnya semakin bertambah pesat, pengaruh ini berimbas kepada ke wilayah mangrove. Kehidupan modern dan kemudahan saluran hasil produksi ekosistem mangrove ke pasaran serta pemanfaatan yang berlebihan tanpa memperhatikan ketentuan kelestarian lingkungan telah berimbas kepada penurunan kuantitas maupun kualitas mangrove itu sendiri. Padahal ekosistem mangrove merupakan zona peralihan antara daratan dan lautan yang mempunyai komparatif sifat lingkungan tajam, yang kelestariannya sangat peka terhadap perubahan lingkungan (Tomlinson, 1986).

Berdasarkan data pada tahun 1984, Indonesia diyakini masih memiliki kawasan hutan mangrove seluas 4,25 ha, kemudian berdasarkan hasil interpetasi Citra Landsat (1992) luasnya tersisa 3,812 juta ha (Ditjen INTAG dalam Martodiwirjo, 1994). Bahkan berdasarkan data Ditjen RRL (1999), luas mangrove Indonesia dalam kawasan hutan hanya seluas 3,7 juta ha, itupun sekitar dengan luas 1,6 juta ha $(43,2 \%)$ nya dalam kondisi rusak parah. Di luar kawasan, Indonesia diperkirakan memiliki mangrove seluas 5,5 juta ha, yang sebanyak 4,8 juta ha $(87,3 \%)$ dalam keadaan rusak parah. Kecepatan kerusakan kawasan mangrove selama 16 tahun, dengan demikian, mencapai lebih dari $134.00 \mathrm{ha} / \mathrm{th}$.

Disaat ini hingga 3 dekade terakhir peningkatan kerusaka hutan mangrove terus terjadi, dimana "hampir $40 \%$ hutan mangrove di Indonesia mengalami berbagi macam kerusakan, kerusakan tersebut sudah masuk ke dalam kerusakan biut" (Balthasar, 2014). Seperti yang kita ketahui bahwa Indonesia merupakan negara kepulauan, dimana hampir 40-50 \% penduduk di Indonesia tinggal di pesisir pantai. Kehidupan dari laut, dengan mata pencaharian sebagai nelayan, dan lain sebagainya. Oleh karena itu penyelamatan hutan mangrove sangat bena bagi seluruh penduduk Indonesia dan penduduk Dunia secara Universal.

Fungsi dan manfaat mangrove tentunya telah banyak diketahui, dimana sebagai tempat berganda ikan-ikan, udang-udang, kepiting-kepiting, siput-siput, dan hewan laut lainnya yang biasa hidup diperairan, perlindungan daratan dari abrasi oleh ombak, pelindung daratan dari tiupan angin, penyaring intervensi air laut ke daratan dan kandungan logam berbahaya bagi kehidupan, tempat singgah migrasi burung, dan sebagai habitat satwa liar, buah manggrove dapat juga diolah menjadi makanan dan minuman, serta manfaat lainnya bagi manusia.

Musibah gempa dan ombak besar tsunami yang melanda Kota Palu pada tanggal 29 September 2018, Nanggroe Aceh Darussalam (NAD) pada tanggal 29 Desember 2004, dan Pulau Nias akhir tahun 2005 yang lalu mengingatkan kembali betapa pentingnya mangrove dan hutan pantai relatif baik, cenderung kurang terkena dampak gelombang tersebut. Hasil penelitian menunjukkan bahwa ketebalan mangrove selebar 200 meter dengan kerapatan 30 pohon/100 meter persegi dengan diameter 15 senti meter dapat meredam sekitar $50 \%$ enersi gelombang tsunami (Harada dab Fumihiko, 2003 dalam Diposaptono, 2005). Gelombang laut setinggi 1,09 meter di Teluk Grajagan, Banyuwangi dengan energi gelombang terbesar 1.493,33 joule tereduksi gelombangnya oleh hutan mangrove menjadi 0,73 meter (Pratikno et al., 2002).

Hasil penelitian Istiyanto er al., (2003) yang merupakan pengujian model di laboratorium antara lain menyimpulkan bahwa rumpun bakau (Rhizophora spp) memantulkan, meneruskan, dan menyerap energi gelombang tsunami yang menerjang pantai. Banyak tempat di Indoneisa ini telah mengalami bencana sebagai akibat dari dampak ketidak-pedulian masyarakat terhadap ekosistem mangrove. Terkikisnya tanah sepanjang 2-3 kilo meter di pesisir pantai Desa Kampung Nelayan Kelurahan Pangkalan Sesai, Kecamatan Dumai Barat, Kota Dumai, merupakan contoh akibat aberasi.

Pengamanan potensi dan fungsi pesisir pantai dilakukan, penetapan kawasan laut, yang sudah dilakukan di beberapa daerah. Hutan mangrove atau hutan pantai sebagai zona penyangga, yang dikelola secara terpadu untuk peningkatan ekonomi masyarakat pantai. Namun, di pihak lain, masih banyak dijumpai sempadan pantai yang tidak memiliki jalur hijau (green belt) mangrove sebagaimana yang telah ditetapkan pada Kepres No. 32 Tahun 1990 tentang Pengelolaan Kawasan Lindung, yaitu $130 \mathrm{x}$ rata-rata tunggang air pasang purnama (tidal range). Namun, pada kenyataannya, ketentuan ini sangat terabaikan pada hampir seluruh hutan mangrove yang ada. Padahal, untuk lebih dapat ditegakkannya supermasi hukum tersebut, dapat dikemukakan beberapa hasil pengamatan informasi ekosistem mangrove yang antara lain adalah bahwa kerusakan 1 ha hutan mangrove akan mengakibatkan kerugian 480 kilo gram ikan, udang, kerang, dan kepiting dilepas pantai pertahunnya (Turner, 1977).

Bahkan Martosubroto dan Naamin (1979) dalam Direktorat Bina Pesisir DKP (2004) Menggambarkan hubungan hasil ikan tangkapan (Y) dan luas hutan mangrove $(X)$ sebagai $Y=0,06+0,15 X$. Sukresno dan Anwar (1999) menunjukkan adanya kecenderungan menurunnya salinitas tanah dengan jarak dari garis pantai, dari $50 \mathrm{mhs}$ di garis pantai, 2-10 mhs pada jarak $0,1 \mathrm{~km}$ hingga $<0,2 \mathrm{mhs}$ pada jarak $>1 \mathrm{~km}$, kecuali pada wilayah yang mangrovenya rusak dapat mencapai $>2$ mhs pada jarak > $1 \mathrm{~km}$. Kondisi air sumurpun pada jarak $1 \mathrm{~km}$ masih tergolong baik untuk wilayah dengan kondisi mangrovenya yang relative baik, sementara pada wilayah dengan mangrove yang tipis sudah terintrusi pada jarak $1 \mathrm{~km}$. jumlah/liter phytoplankton dan zooplankton sebagai sumber makanan ikan 
cenderung meningkat dengan makin luasnya dan makin bertambahnya usia tanaman mangrove (Marsono et al., 1995: Anwar dan Sumarna, 1987). Bahkan hasil Gunawan et al., (2007) memaparkan adanya kandungan logam berat berbahaya, Merkuri $(\mathrm{Hg})$ pada tanah di tambak terbuka adalah 16 kali dibandingkan dengan pada yang memiliki hutan mangrove. Di samping itu, kandungann $\mathrm{Hg}$ dalam ikan atau udang pada tambak tanpa mangrove cenderung lebih tinggi dari pada tambak yang ada hutan mangrovenya (Gunawan dan Anwar, 2008).

Dilihat dari kondisi yang ada di atas tergambar bahwa betapa pentingnya pelestarian dan penanaman hutan mangrove pada wilayah pesisir pantai. Banyak pengaruh positif dari pelestarian hutan mangrove itu sendiri, dampak dari itu tidak hanya berpengaruh kepada penduduknya saja, namun akan berpengaruh lebih baik pula pada keanekaragaman ekosistem laut dan pelestarian lingkungan laut, dan tentunya ada manfaat ekonominya, dimana sebuah kawasan mangrove yang bagus, bisa menjadi daerah ekowisata tentunya.

Untuk menjawab penyelesaian masalah tentang pentingnya pelestarian hutan mangrove sebagai penyeimbang ekosistem, dan menjadi ekowisata mangrove untuk peningkatan perekonomian masyarakat sekitar. Corporate Social Reponsibility $(C S R)$ PT. Pertamina (Persero) MOR-1 Terminal Bahan Bakar Minyak (TBBM) Dumai memberikan perenovasian fasilitas wisata yang ada di kawasan hutan mangrove sebagai tempat yang nyaman untuk wisatwan dan pengunjung pecinta mangrove. Namun, hal tersebut tidak berhenti di situ saja Corporate Social Reponsibility (CSR) PT. Pertamina (Persero) MOR-1 Terminal Bahan Bakar Minyak (TBBM) Dumai, juga memberikan pelatihan, pendampingan, edukasi, dan sosialisai tentang pentingnya pelestarian hutan mangrove bagi kehidupan dunia, yang diiringi dengan penanaman 3000 batang pohon mangrove yang di pusatkan di Desa Wisata Kampung Nelayan Kelurahan Pangkalan Sesai, Kecamatan Dumai Barat, Kota Madya Dumai.

\section{METODE PELAKSANAAN}

Metode pelaksanaan kegiatan renovasi bangunan di kawasan Desa Wisata Kampung Nelayan dan penanaman 3000 batang pohon mangrove di Desa Wisata Kampung Nelayan ini, merupakan kombinasi kegiatan peningkatan ekowisata mangrove dengan perbaikan fasilitas dan pelestarian hutan mangrove dengan menanam 3000 mangrove untuk pelestarian kehidupan yang lebih baik, yaitu dengan melakukan: (1) perenovasian bangunan di kawan Desa Wisata Kampung Nelayan dan (2) penanaman 3000 batang pohon mangrove. Secara terperinci dapat dilihat pada uraian berikut ini:

\section{1) Renovasi Fisik Bangunan}

Kawan desa Wisata Kampung Nelayan, sudah ada bangunan-bangunan penarik wisatawan untuk dapat berkunjung ke sini, dengan fasilitas seperti, jalan panggung, tempat meeting, perpustakaan, foodcourt, aula, arena bermain bagi anak-anak, WC, dan falitas umum lainnya. Kondisi ini bisa dikatakan sudah rusak berat "rusak berat adalah kerusakan pada komponen struktur yang dapat mengurangi kekuatannya sehingga kapasitas layan struktur sebagian atau seluruh bangunann dalam kondisi tidak aman, yaitu terjadi apabila dinding pemikul beban terbelah dan runtuh, bangunan terpisah akibat kegagalan unsur pengikat dan $50 \%$ elemen utama mengalami kerusakan atau tidak layak huni (Ditjen Cipta Karya, 2006). Hal ini diakibatkan oleh, tidak terawat dengan baiknya sehingga banyak kondisi dari bangunan yang sudah rusak dan tidak layak pakai. Tentunya kondisi ini sangat berpengaruh kepada kuantitas pengunjung dan estetika lingkungan wisata mangrove Kampung Nelayan ini. Pihak Corporate Social Reponsibility (CSR) PT. Pertamina (Persero) MOR-1 Terminal Bahan Bakar Minyak (TBBM) Dumai tidak ini melihat kondisi ini terus berkelanjutan, untuk memalangi itu semua, pihak CSR PT. Pertamina yang dibantu oleh masyaraakat, pemda, komunitas pecinta alam, dan rumah zakat melakukn renovasi dan membangun kembali bangunan-bangunan yang sudah tidak layak pakai.

\section{2) Penanaman 3000 Pohon Mangrove}

Teknik penanaman pada delta terdegradasi, yang dilakukan oleh Corporate Social Reponsibility (CSR) PT. Pertamina (Persero) MOR-1 Terminal Bahan Bakar Minyak (TBBM) Dumai, diperoleh melalui kegiatan: Penanaman 3000 batang pohon mngrove berbagai jenis mangrove pada jarak tanam dan berbgai sistim jalur tanam, Pengamatan pertumbuhan anakan mangrove pada berbagai perlakuan; dan Pengamatan perubahan kualitas perairan dan substrat tanah setelah 4 tahun pertama;

Teknik penanaman pada areal teraberasi dan pulaupulau kecil untuk penanaman pada areal teraberasi akan diperoleh melalaui kegiatan: penanaman 3000 pohon mangrove pada berbagai jenis pecahan dan atau peredam ombak, percobaan pemberian perlakuan perbedaan fisik pelindung ombak terhadap keberhasilan pengurangan tingkat aberasi, pengamatan keberhasilan tanaman mangrove yang ditanam di sebelah dalam pelindung ombak, dan pengamatan perubahan kualitas perairan dan substrat tanah setelah 4 tahun penanaman. Untuk penanam pada pulau kecil akan diperoleh melalui kegiatan: percobaan penanaman berbagai jenis mangrove dengan berbagai jarak tanam (salah satu perlakuan dengan jarak rapat) dan jalur jarak, pengamatan keberhasilan tanaman mangrove, dan pengamatan perubahan kualitas dan substrat tanah setelah 4 tahun penanaman. Kajian sistem kelembagaan rehabilitasi mangrove: kajian motivasi masyarakat tentang pentingnya hutan mangrove dipesisir pantai, serta keikutsertaannya pada rehabilitasi mangrove dan kajian organisasi, peran dan fungsi lembaga rehabilitasi mangrove, seperti kelompok pecinta alam, masyarakat sekitar, pemerintahan daerrah dan pihak swsata seperti 
rumah zakat yang ada di kawasan di Desa Wisata Kampung Nelayan Kelurahan Pangkalan Sesai, Kecamatan Dumai Barat, Kota Madya Dumai.

Kajian pelesapan polutan perairan oleh jenis-jenis mangrove, diperoleh melalui kegiatan: penetapan plot pengamatan berupa tambak atau empang berbagai perbedaan tutupan mengrove serta pada hutan mangrove, analisis kandungan polutan perairan yang terkandung pada substrat, perairan, ikan, dan bagian tanaman mangrove yang diambil dari tambak yang berbeda jenis mangrovenya, dan analisis kandungan polutan yang terjerap oleh bagian tanaman berbagai jenis mangrove. Kajian jenis-jenis mangrove akan diperoleh melalui kegiatan: penanaman 3000 pohon mangrove Avicennia spp., Sonneratia spp, dan Rhizophora spp. Dalam dua macam jarak tanam dan analisis laju sediman terlarut yang dijerat oleh masing jenis tanaman dan jarak tanam, sebagai bentuk seberapa perkembangan phon mangrove jika jarak tanam diarapatkan dan sebaliknya.
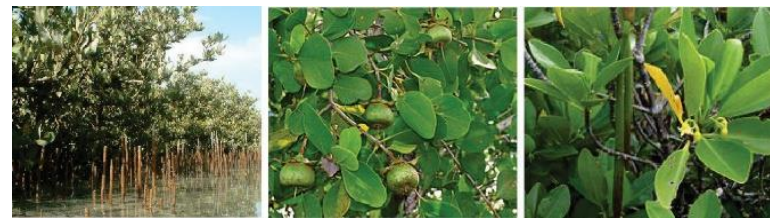

Gambar 1. Jenis Mangrove Avicennia spp., Sonneratia spp, dan Rhizophora spp.

\section{HASIL KEGIATAN DAN PEMBAHASAN}

Hasil renovasi dan penanaman 3000 pohon mangrove di Desa Wisata Kampung Nelayan Kelurahan Pangkalan Sesai, Kecamatan Dumai Barat, Kota Madya Dumai. Mengalami perbaikan kondisi lingkugan tentunya, dari data yang sebelumnya rendah sekarang mengalami peningkatan dari masing-masing capaian indikator yang dilihat, untuk lebeh jelas dapat dilihat pada penjelasan berikut ini.

\section{1) Renovasi Fisik Fasilitas Umum di Kawasan Wisata Desa Kampung Nelayan.}

Tabel 1. Persentase Komparasi Renovasi Fisik

\begin{tabular}{|c|l|c|c|c|c|}
\hline \multicolumn{7}{|c|}{ Bangunan } \\
\cline { 3 - 6 } o & \multicolumn{1}{|c|}{ Perbaikan } & \multicolumn{4}{|c|}{ Kriteria } \\
\hline Fasilitas & S & B & CB & KB \\
\hline 1. & $\begin{array}{l}\text { Tersedianya jalan } \\
\text { panggung yang } \\
\text { memenuhi Standar } \\
\text { Nasional }\end{array}$ & $\sqrt{ }$ & & & \\
\hline 2. & $\begin{array}{l}\text { Fasilitas umum } \\
\text { tempat buang air }\end{array}$ & & $\sqrt{ }$ & & \\
\hline
\end{tabular}

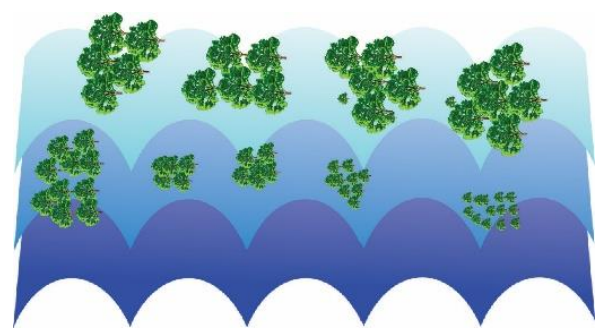

Gambar 2. Penanaman Pulau-pulau Kecil Disepanjang Pesisir Pantai.

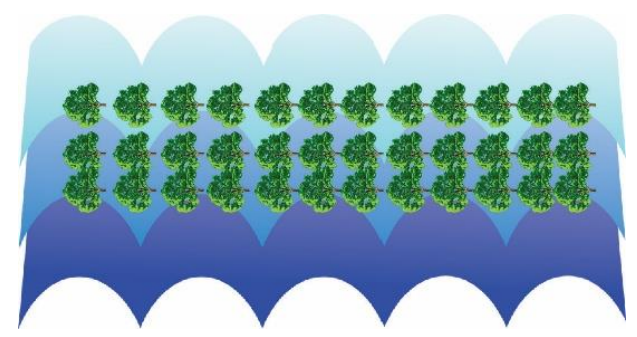

Gambar 3 . Penanaman Jarak Rapat.

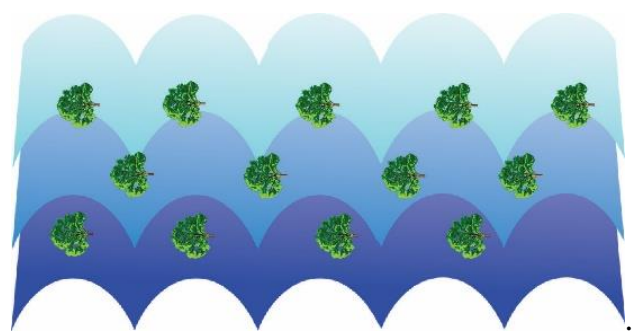

Gambar 4 . Penanaman Jarak Renggang.

\begin{tabular}{|c|c|c|c|c|}
\hline & $\begin{array}{l}\text { kecil dan besar } \\
\text { yang bersih dan } \\
\text { sehat }\end{array}$ & & & \\
\hline 3. & $\begin{array}{l}\text { foodcourt yang } \\
\text { memenuhi standar } \\
\text { kesehatan }\end{array}$ & & $\sqrt{ }$ & \\
\hline 4. & $\begin{array}{l}\text { Rumah baca bagi } \\
\text { pengunjung }\end{array}$ & $\sqrt{ }$ & & \\
\hline 5. & $\begin{array}{l}\text { Buku tentang } \\
\text { pengetahuan } \\
\text { mangrove }\end{array}$ & $\sqrt{ }$ & & \\
\hline 6. & $\begin{array}{l}\text { Arena bermain } \\
\text { anak-anak yang } \\
\text { dilengkapi safety } \\
\text { berstandar }\end{array}$ & $\sqrt{ }$ & & \\
\hline 7. & $\begin{array}{l}\text { Papan informasi } \\
\text { panduan jalan dan } \\
\text { hal penting lainnya }\end{array}$ & $\sqrt{ }$ & & \\
\hline 8. & $\begin{array}{l}\text { Papan informasi } \\
\text { penjelasan jenis- } \\
\text { jenis mangrove }\end{array}$ & $\sqrt{ }$ & & \\
\hline \multicolumn{4}{|c|}{ Subtotal } & 24 \\
\hline \multirow{2}{*}{\multicolumn{4}{|c|}{$\begin{array}{l}\text { Rata-rata } \\
\text { Persentase }\end{array}$}} & 3,62 \\
\hline & & & & $75 \%$ \\
\hline
\end{tabular}


Keterangan:

$$
\begin{array}{ll}
\text { SB } & \text { : Sangat Baik (4) } \\
\text { B } & \text { : Baik (3) } \\
\text { CB } & \text { : Cukup Baik (2) } \\
\text { KB } & \text { : Kurang Baik (1) }
\end{array}
$$

Fisik bangunan yang ada dikawan desa wisata Kampung Nelayan, Kelurahan Pangkalan Sesai, Kecamatan Dumai Barat, bisa dikatan tidak layak pakai atau layak guna di mana bisa dikatakan secara umum rusak parah. Setelah Corporate Social Reponsibility (CSR) PT. Pertamina (Persero) MOR-1 Terminal Bahan Bakar Minyak (TBBM) Dumai, melakukan pembenahan keadaan tersebut terjadi perubhan dari masing-masing fasilitas yang ada tersebut mulai dari jalan panggung menjadi lebih sangat baik, tempat buang air atau WC umum sudah baik, area makanan menjadi tertata rapi dapat dikelompokkan ke kategori cukup baik, rumah baca menjadi baik, buku-buku tentang pengetahuan mangrove sudah membaik, area bermain anak kategori baik, informasi-informasi penting dan buku pengetahuan tentang mangrove sudah baik. Secara keseluruhan sudah masuk ke dalam kategori sangat baik dengan rata-rata 3,62.

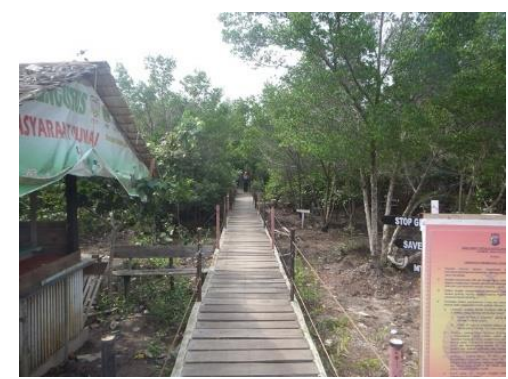

Gambar 5 . Jalan Panggung Kawasan Wisata Desa Nelayan

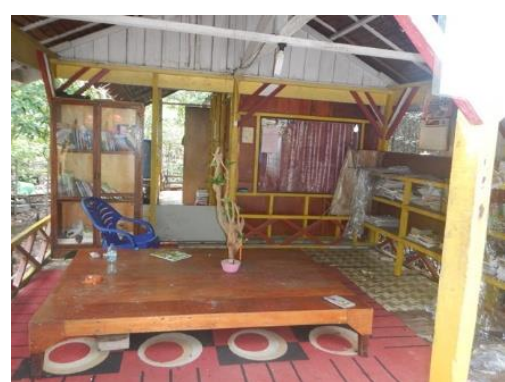

Gambar 6 . Pustaka Mangrove Kawasan Wisata Desa Nelayan

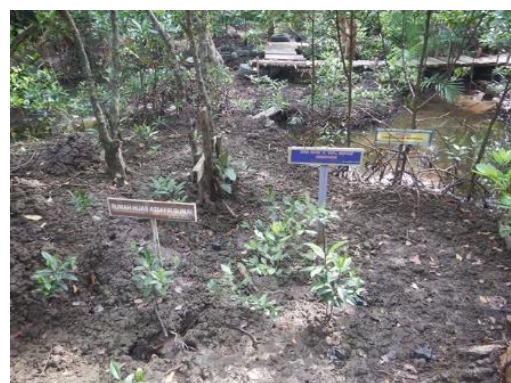

Gambar 7 . Pengetahuan Jenis-jenis Mangrove
Banyak dampak dari perubahan kondisi tersebut di atas salah satunya meningkatnya pengunjung yang datang ke tempat ini dan tentunya secara tidak langsung tingkat perekonomian masyartakat setempat menjadi lebih baik. Dimana pengunjung yang disebut sebagai konsumen akan lebih banyak berkunjung ke desa wisata ini, "dengan memperhatikan kepuasan konsumen, maka sebuah usaha atau wisata dapat mempertahankan keberadaan konsumennya (Kotler dan Keller, 2012: 3-140).

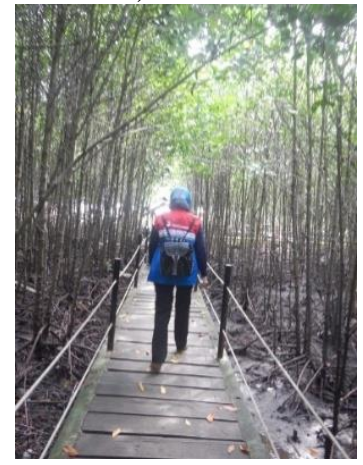

Gambar 8 . Tim CSR Pertamina Memantau Kondis di Lapangan

\section{2) Penanamn 3000 Pohon Mangrove}

Penanaman 3000 ribu pohon mangrove, dilakukan untuk pelestarian lingkungan hutan mangrove, supaya tidak terjadi abrasi dan hal lain yang bisa membuat kerusakan ekosistem laut lainnya, banyak pengaruh yang berarti dengan adanya hutan mangrove di sepanjnag pesisir pantai. Corporate Social Reponsibility (CSR) PT. Pertamina (Persero) MOR-1 Terminal Bahan Bakar Minyak (TBBM) Dumai, malukan kegiatan ini dengan capaian output sebagai berikut:

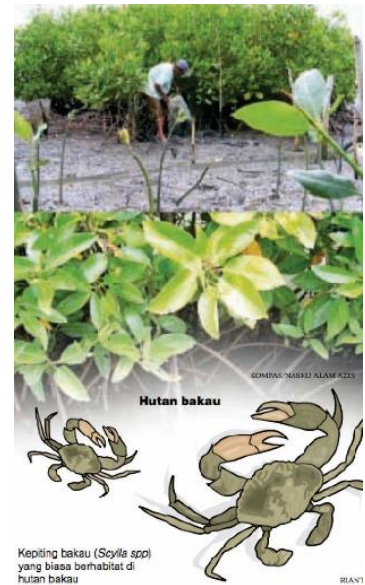

Gambar 9. Pentingnya Hutan Mangrove bagi Pelestarian Ekosistem Laut.

Tabel 2. Persentase Peningkatan Pasca Penanaman 3000 Pohon Mangrove

\begin{tabular}{|c|l|c|c|c|c|}
\hline \multirow{2}{*}{ No } & \multirow{2}{*}{$\begin{array}{c}\text { Program } \\
\text { Kegiatan }\end{array}$} & \multicolumn{4}{|c|}{ Kriteria } \\
\cline { 3 - 6 } & SB & B & CB & KB \\
\hline 1. & $\begin{array}{l}\text { Tersedianya teknik } \\
\text { penanaman }\end{array}$ & & $\sqrt{ }$ & & \\
\hline
\end{tabular}




\begin{tabular}{|l|l|l|l|l|l|}
\hline & $\begin{array}{l}\text { mangrove pada } \\
\text { delta terdegradasi }\end{array}$ & & & & \\
\hline 2. & $\begin{array}{l}\text { Tersedianya teknik } \\
\text { penanaman } \\
\text { mangrove } \\
\text { disepanjang pesisir } \\
\text { pantai dan small } \\
\text { islands }\end{array}$ & & $\sqrt{ }$ & & \\
\hline 3. & $\begin{array}{l}\text { Tersedianya } \\
\text { tekknik } \\
\text { penanggulangan } \\
\text { aberasi }\end{array}$ & $\sqrt{ }$ & & & \\
\hline 4. & $\begin{array}{l}\text { Tersedianya sistem } \\
\text { kelembagaan } \\
\text { rehabilitasi }\end{array}$ & $\sqrt{ }$ & & \\
\hline 5. & $\begin{array}{l}\text { Bertambahnya data } \\
\text { base keragaman } \\
\text { satwa }\end{array}$ & $\sqrt{ }$ & & \\
\hline 6. & $\begin{array}{l}\text { Bertambahnya data } \\
\text { base keragaman } \\
\text { mikroorganisme }\end{array}$ & $\sqrt{|c|}$ Persentase & & \\
\hline 7. & $\begin{array}{l}\text { Bertambahnya data } \\
\text { base potensi wista } \\
\text { mangrove }\end{array}$ & $\sqrt{|c|}$ Subtotal & & \\
\hline 8. & $\begin{array}{l}\text { Tersedianya } \\
\text { informasi sosial } \\
\text { ekonomi } \\
\text { silvofishery }\end{array}$ & $\sqrt{ }$ & & \\
\hline & \multicolumn{4}{|c|}{ Rata-rata } \\
\hline
\end{tabular}

Banyaknya terjadi aberasi dikawsan Desa Wisata Kampung Nelayan, Kelurahan Pangkalan Sesai, Kecamatan Dumai Barat, bisa dikatakan kedalam kategori yang cukup memprihatinkan, setelah Corporate Social Reponsibility (CSR) PT. Pertamina (Persero) MOR-1 Terminal Bahan Bakar Minyak (TBBM) Dumai, melakukan kegiatan rehabilitasi hutan mangrove untuk mengatasi abrasi dengan penanaman 3000 pohon mangrove, dengan berbagai bentuk kegiatan, maka berdampak pada kategori baik dari hasil pembenahan tersebut. Seiring yang disampaikan oleh Sugandhy dalam Meika (1994:10) bahwa permasalahan yang terjadi di kawasan hutan mangrove yaitu berkaitan dengan kelestarian fungsinya. Di sini permasalahn tersebut telah dilakukan pembenahan oleh Corporate Social Reponsibility (CSR) PT. Pertamina (Persero) MOR-1 Terminal Bahan Bakar Minyak (TBBM) Dumai, dengan tinkat pencapaian berada pada kategore baik yaitu rata-rata 3,12 dan pesentasenya $78 \%$.

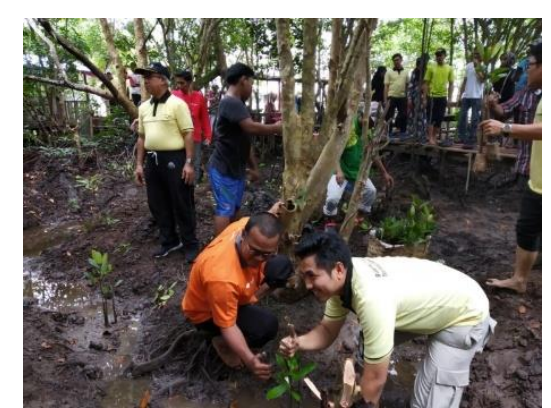

Gambar 10. Penanaman 3000 Pohon Mangrove

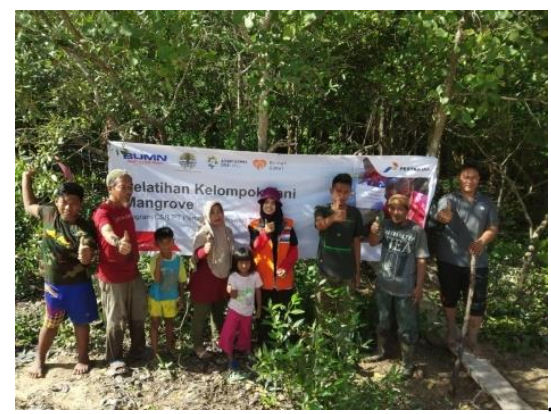

Gambar 11. Kegiatan Pelestarian Hutan Mangrove oleh CSR Pertamina

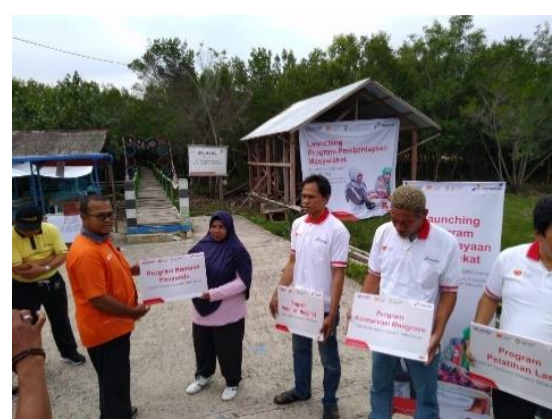

Gambar 12. Penyerahan Bantuan dari CSR Pertamina untuk Pelestarian Ekowista Mangrove

\section{KESIMPULAN DAN SARAN}

Pelaksanaan program Renovasi Fisik dan Penanaman 3000 Pohon Mangrove oleh Corporate Social Responsibility (CSR) PT. Pertamina (Persero) Mor-1 Dumai di Desa Wisata Kampung Nelayan Kelurahan Pangkalan Sesai, Kecamatan Dumai Barat, Kota Madya Dumai, berjalan sesuai dengan harapan. Hal ini dapat dilihat dengan beberapa indikator capaian: 1) renovasi fisik fasilitas umum di kawasan wisata desa kampung nelayan, dapat di kategorikan pada peningkatan membaik dengan persentase mencapai pada $75 \%$ dalam perubahan fisik bangunan yang ada di kawasan wisata desa kampung nelayan, selanjutnya untuk kegiatan penanaman 3000 pohon mangrove 2). Penanaman 3000 pohon mangrove berada pada peningkatan jumlah pohon mangrove yang ada di Desa Wisata Kampung Nelayan, Kelurahan Pangkalan Sesai, Kecamatan Dumai Barat, Kota Madya Dumai, mengalami peningkatan kepada kategori membaik, dengan capaian persentase $78 \%$. 
Kegitan ini tentunya memberikan kontribusi yang sangat berarti bagi perkembangan Desa Wisata Kampung Nelayan menjadi lebih baik lagi dengn kondisi fasilitas yang lebih baik, diharapkan kepada seluruh masyarakat untuk tetap menjaga fasilitas yang ada dengan melakukan perawan fisik bangunan yang ada di sekitar objek wisata, dimana bangunann ini akan menjadi penyangga keberlangusungan pariwisata yang lebih baik.

Penanaman 3000 pohon mangrove sangat memberikan kontribusi yang besar bagi dunia untuk kelangsungan ekosistem laut lebih baik lagi, namun hal ini tidak hanya berpatokan dengan ekosisntem saja, pelestaraian hutan mangrove juga memberikan manfaat yang sangat berarti bagi penduduk disekitar manggrove, peminimalisiran bahaya bencana besar, mata pencaharian meningkat, dan tentunya keindahan hutan mangrove memiliki daya tarik tersendiri bagi pengunjung, pastinya daerah tersebut akan menjadai ekowisata yang diminati. Perhatian masyarakat untuk menjaga kebersihan daerah ekowista sangat urgen untuk dilakukan dan kegitan sadar lingkungan lainnya.

\section{DAFTAR PUSTAKA}

Tomlinson, P.B. 1986. The Botany of Mangroves. Inggris: Cambridge University Press.

Anwar, C. dan Y. Sumarna. 2007. Sinthesis Hasil Penelitian Teknologi dan Kelembagaan Rehabiliasi Hutan Mangrove. Draft awal. Pusat Litbang Hutan dan Konservasi Alam. Bogor: -

Anwar, C. dan Y. Sumarna. 1987. Populasi Phitoplankton pada Beberapa Perairan Hutan Mangrove Cilacap. Bulletin Penelitian Hutan, No. 492: 28-37. Pusat Penelitian dan Pengembangan Hutan. Bogor:-

Balthasar, Hans Urs Von dan Karl Barth. 2006.

University of Birmingham Research Archive. London: The University of Birmingham.

Departemen Kehutanan. 2004. Statistik Kehutanan Indonesia, Frorestry Statistics of Indonesia 2003. Badan Planologi Kehutanan, Departemen Kehutanan, Jakarta.

Departemen Kehutanan. 2008. Statistik Kehutanan Indonesia, Forestry Statistics of Indonesia 2007. Badan Planologi Kehutanan, Departemen Kehutanan, Jakarta.

Diposaptono. S. 2005. Rehabilitasi Pascatsunami yang Ramah Lingkungan. Kompas, 10 Januari 2015.

Direktorat Bina Pesisir. 2004. Pedoman Pengelolaan Ekosistem Mangrove. Ditjen Pesisir dan PulauPulau Kecil, DKP. Jakarta.

Ditjen Reboisasi dan Rehabilitasi Lahan. 1999. Inventarisasi dan Identifikasi Hutan Bakau (Mangrove) yang Rusak di Indonesia. PT Insan Mandiri Konsultan. Jakarta:-

Gunawan, H., C. Anwar, R. Sawitri, dan E. Karlina. 2007. Status Ekologis Silvofishery Pola Empang Parit dan Bagian Pemangkuan Hutan CiasemPamanukan, Kesatuan Pemangkuan Hutan Purwakarta. Jurnal Penelitian Hutan dan
Konservasi Alam Vol. IV No. 4 (429-439): 2007.

Gunawan, H. dan C. Anwar. 2008. Kualitas Perairan dan Kandungan Merkuri (Hg) dalam Ikan pada Tambak Empat Parit di BKPH CiasemPamanukan, PKH Purwakarta, Kabupaten Subang, Jawa Barat. Jurnal Penelitian Hutan dan Konservasi Alam vol. V No. 1 (1-10): 2008.

Istiyanto, D.C., S.K. Utomo, dan Suranto, 2003. Pengaruh Rumpun Bakau terhadap Perambatan Tsunami di Pantai: Makalah pada Seminar Nasional "Mengurangi Dampak Tsunami: Kemungkinan Penerapan Hasil Riset" di Yogyakarta, 11 Maret 2003.

Martodiwirjo, S. 1994. Kebijaksanaan Pengelolaan dan Rehabilitasi Hutan Mangrove dalam Pelita VI. Bahan Diskusi Panel Pengelolaan Hutan Mangrove, Mangrove Center, Denpasar, 26-28 Oktober 1994

Marsono, D., E.P. Rahayu, dan Udiono. 1995. Peran Rehabilitasi Mangrove Terhadap Keanekaragaman Biota (Studi Kasus di Pantai Pemalang).

Pratikno, W.A., Suntoyo, K. Sumbodho, Solihin, Taufik dan D. Yahya, 2002. Perencanaan Perlindungan Pantai Alami untuk Mengurangi Resiko terhadap Bahaya Tsunami. Makalah Lokakarya Nasional Pengelolaan Ekosistem Mangrove, di Jakarta, 6-7 Agustus 2002.

Tomlinson, P.B. 1986. The Botany of Mangroves. Inggris: Cambridge University Press.

Turner, R.E. 1977. Intertidal Vegetation and Commercial Yields of Penaeid Shrimp. Trans. Am. Fish. Soc. 106: 411-416.

Kotler, dan Keller. 2012. Manajemen Pemasaran. Edisi 12. Jakarta: Erlangga.

Direktorat Jenderal Cipta Karya Kementrian Pekerjaan Umum. 2010. Rencana Strategis Direktorat Jenderal Cipta Karya 2010-2014.

Meika, Rizka. 2010. Upaya Pelestarian Hutan Mangrove Berdasarkan Pendekatan Masyarakat. Bengkulu: -

Keputusan Presiden No. 32 Tahun 1990 Tentang Pengelolaan Kawasan Lindung. 